\title{
Lexical Features of Arabic Internet Sayings for Women
}

\section{A. O. Kucherenko}

\author{
Taras Shevchenko National University of Kyiv \\ Corresponding author. E-mail: k.alina1092@gmail.com
}

Paper received 30.03.18; Accepted for publication 03.04.18.

\section{https://doi.org/10.31174/SEND-Ph2018-161VI48-10}

\begin{abstract}
This paper deals with lexical means of Arabic Internet sayings for women. The study refers to modern aphorisms, witticisms, motivational phrases and so forth. They reflect the language utilized in everyday communication. On the one hand, Arabic variety covers standard and colloquial languages which can be mixed to facilitate the understanding between Arabs from different countries. A special attention is also given to the code-switching and the code-mixing between Modern Standard Arabic and Colloquial Arabic. On the other hand, we consider the impact of the Internet on Arabic and analyze the creative aspect that affects the female discourse online.
\end{abstract}

Keywords: Internet saying, female discourse, Arabic variety, lexical interference, colloquialism.

Introduction. The World Wide Web contains dozens of online communities targeted for different social, ethnic, religious and gender groups, etc., which discover the opportunity for creative activities and lead to the creation of folk-groups with esoteric and exoteric traditions. Gender groups are frequently promoted by commercial structures such as online journals. Media resources use additional platforms, for instance Facebook, to gain the bigger number of followers and, consequently, customers. However, the advertisement on social media should be diluted in order to avoid negative reactions and, hence, we observe how additional instruments can serve to attract people. Such tools embrace the so-called postfolkloric texts $^{1}$, including Internet memes, wise sayings, witty expressions and so forth.

On the other hand, language variation on the Internet reflects linguistic peculiarities of the aforementioned online folk-groups. For Arabic language, the variety covers Modern Standard Arabic (i.e. a literary form), Colloquial Arabic and Latinized Arabic (i.e. Arabizee). Colloquial Arabic, in its turn, is represented with 18 dialects [9, p. 22]. In addition, we should consider another language form affected by modern technologies, global tendencies and linguistic interferences leading to the language convergence. It has some features of the Internet slang. This paper deals with lexical means utilized in Arabic sayings on the web which cover colloquialisms, slang words, modern loanwords and other.

Literature Review. The language of Internet posts is studied through blogging by S. Hadžiahmetović Jurida in "Linguistic Properties of Blogging within the Aspect of Netspeak" [4], S. C. Herring, I. Kouper, J. C. Paollilo, E. Wright and others. Z. A. Kadir, M. Maros, and B. A. Hamid provided the research on the linguistic features of online forums [6]. Linguistic gender variation in online communication is studied by J. Guiller and A. Durndell ('Students' linguistic behaviour in online discussion groups: Does gender matter?") [3], J. Androutsopoulos ("From Variation to Heteroglossia in the Study of Computer-Mediated Discourse" 2011) and others [2]. Gender peculiarities in English on Facebook are outlined by S. H. Thompson and E. Lougheed ("Frazzled by Facebook? An

\footnotetext{
${ }^{1}$ Postfolkloric texts refer to the phenomenon of postfolklore. The term was offered by the Russian scholar S. Nekludov to describe the modern folk creativity which developed under new traditions, forms and ways of transmission [7, p. 2]
}

exploratory study of gender differences in social network communication among undergraduate men and women" 2012) [8]. A linguistic study of gender and politeness strategies in Arabic on Facebook is investigated by Safaa Al-Shlool [1]. S.O. Jarbou and B. Al-Share consider the gender factor of phonetic variation in Jordanian Arabic in the computer-mediated communication [5]. Various aspects of gender variation in Arabic are studied by M. A. Harb, A. A. Humei, M. Al-Fattah and others. Still, the lexis of female discourse considering the creative manipulation with Arabic language on Facebook lacks a thorough analysis. It causes the need to study the language gender difference in a particular social context.

The objective of this article is to analyze female Internet sayings in Arabic in order to examine the informal vocabulary of a modern Arabic woman utilized in everyday situations.

Methodology and materials. We analyze Internet posts on the Facebook community "Women" targeted for female users [12]. The study is focused on the lexicon of Internet sayings covering different forms of Arabic online. We also make an emphasis on the creative manipulation with the language including the wordplay that results in the usage of occasionalisms, nonce words and other. Nearly 500 samples were collected and qualitatively analyzed. The author explicates the correlation between the colloquial and the literary lexis in various sayings, as well as the impact of extralinguistic factors on the Arabic language variation in the aforementioned online community. The provided data refers to educated Arabic female recipients in the age between $18-34$ years $^{2}$.

Results and discussion. Internet sayings are represented with aphorisms (including pseudo-aphorisms), mottos, witticisms, cliché, idioms and other. In postfolklore, we observe the rethinking of traditional sayings, the relexicalization of idiomatic expressions and, of course, the creation of new texts referring to the contemporary life. Internet sayings have common features with posts in blogs and microblogs and, hence, they reflect the everyday language utilized in social media.

As G. Ramsay mentions, the code-switching in Egyptian blogs occurs between MSA and Egyptian Arabic [10, p. 50]. It is assumed, that the blogging language contains insertions of dialects and it is called by some linguists the

\footnotetext{
${ }^{2}$ According to the New Global Social Media Research, the biggest number of Facebook users are 18 - 34 years [11]
} 
'mixed variety' [10, p. 50]. According to R. Bassiouney, the code-switching in the informal media discourse is typical for both genders [10, p. 49]. Ramsay comes to the conclusion that bloggers utilize some mixed variety of Arabic which, depending on the situation and the recipients, relies on a particular language variant with elements of the other language form (MSA mixed with Colloquial Arabic, mixing of regional dialects, and even Classic Arabic) [10, p. 83]. The similar language situation can be found in the everyday communication between representatives of different Arabic countries in the real world. Scholars admit the code-switching and the code-mixing between different Arabic dialects within one message. This research contains instances of code-mixing in Internet sayings for women that occurs at lexical (mundu duhūli li-tilka al-ğāmi 'a 'since I entered that university'), morphological (e.g. verbs with affix $b i$, the ending $\bar{i} n$ instead of $\bar{u} n$ ignoring the grammatical case, etc.), phonetic (substitution ' $y \bar{a}$ - alif maqșūra') and syntactic (ta 'rif tafruq 'knows how to distinguish' with the omitted particle an) levels. Additionally, we observe the codeswitching (for instance, one part of a message is provided in MSA and the other one is a colloquial or a mixed variety). The author focuses on the lexical features of the given phenomenon.

The first place among other posts is occupied by motivational phrases. For instance, tamassaki bi-tilka al-lahza allatì taḥtafilì fi-hā bi-inğāzāti-k wa tafawwuqi-k, iğ 'alīhà dāfi' li-l-mazìd min an-nağāh fì hayāti-k almustaqbala (keep the moment when you are celebrating your achievements and superiority, make it an impulse for the further success in your future life). Though the text is written in MSA, two issues indicate to the usage of the so-called 'āmmiyyatu-l-mutaqqafin (Colloquial Arabic of intellectuals) - tamassaki bi-tilka al-lahza (keep the moment) is an expression used in the colloquial variant and iğ 'ali-ha da $\bar{a} f$ ' (make it an impulse), which is also taken from the oral speech where the endings are truncated (iğ 'alì-hā dāfi 'an in MSA).

The motivation can be expressed implicitly: al-qararāt allatī yaṣna 'u-hā kibriyā'u-k șầ'iba wa in awğa'at-ki (decisions made by your dignity are right, even though they cause pain). This expression reflects the lexical interference in Arabic online creativity. The idea has probably been borrowed from the English social networking content. The collocation 'make a decision' in MSA is transmitted with the equivalent 'ittahada qarāran'. However, the above text contains a calqued expression from English - șana'a qarāran.

Sayings addressing men can possess either a positive or a negative attitude in a message. But an implicit encouragement to 'stay yourself' remains an important part of motivational texts: 'azizzì, in kunta tabhat 'an al-kamāl wa al-mitāliyya fa-anā last al-mar'a al-munāsiba la-k, ammā in kunta tabhat 'an aṣ-șidq wa al-maraḥ wa alkațīr min al-ğunūn fa-tilka anā (My dear, if you are looking for an excellent and a perfect woman then I am not a good match for you, but if you are looking for sincerity, joy and a lot of craziness, that is me). Note here, that lexemes with general positive meaning (kamāl 'excellence' and mițaliyya 'perfection') are perceived negatively, with some criticism of a hyperbolized image of a nonexisting woman who, however, represents the men's ide- al. That is, of course, from the female's point of view (and it has a corresponding reaction in the comments from male users arguing the given point). On the other hand, a lexeme having mostly the negative meaning in the literary language (ğunūn 'craziness'), or relating to some strong feeling to a person, gains the positive connotation 'doing something unusual, unexpected, entertaining'. At this point, we suggest that the case of the word ğunūn can be a result of language and culture contacts online, because the aforementioned connotation is typical for the western social media content. Additionally, the expression fa-tilka $a n \bar{a}$ (and that is me) proves the fact of linguistic interference in the studied online community as it literally represents an English text in Arabic words.

Modern female aphorisms tend to use MSA as well: ar-rağul lā yastațī' an yakūna qāsiyan ma'a imra'a yuhibbu-hā (a man cannot be cruel with a woman he loves). Another sample contains the features of Colloquial Arabic - lā tasta' '̆ilū al-hubba... sa-ya'tī waqt wa taktašif anna hunāk man yastahiqq al-intizāar (do not hurry love... The time will come and you will understand that there is a man who deserves waiting) - the verb taktašif (here 'understand') is utilized in a unified colloquial form having no indications to the gender (unlike MSA).

Aphorisms frequently provide rich linguistic data considering the creative aspect, i.e. the language game. For instance, the desire to create a unique expression on the everlasting female topics (love, suffering and men) can result in an interesting wordplay: miš al-ğ $\bar{u}$ ' bess ili kâfir, al-ḥubb kāfir, wa at-ta'alluq kāfir, wa al-masāfāt kāfira, wa al-hanīn li-l-mậ̂̄ di min al-kabā'ir (not only the hunger can be severe, but the love is bitter, the liaison is brutal, the distances are tough, as well as longing for the past - all they are sins). In the original variant, epithets are represented with the only one lexeme - kâfir - that is utilized in MSA in the collocation al-ğ $\bar{u}$ ' al-kāfir (a severe hunger). Thereafter it is added to every word as a modifier 'tough'. Hence, the text expresses the negative emotional state.

Aphorisms about love are popular among female users. They may be a part of the motivational content. Both Standard and Colloquial Arabic forms can be applied. The lexis is mainly related to emotions. Al-ihtiyāğ min ahtar marāḥil al-ḥubb. Immā tuzhhir iḥtiyāğg-k li-š-šahs ilī bithibbu-h wa huwa ma-yuqaddiru-š bithiss sā'ata-hā inna-k ta'arreyt quddāma-h wa bitabaqqā da'îf wa sā'ata-hā byanhār al-hubb di. (Neediness is one of the most dangerous stages of [being in] love. When you show your neediness to a person you love and he / she does not value that, sometimes you feel like you are undressed and weak in front of that person, but sometimes this love dies [at all]). The above text is written in Colloquial Arabic (colloquial variant $i l \bar{i}$ (that), verbs in the colloquial form with affix $b i$, etc.). The colloquialism $d i$ (this) indicates to the Egyptian dialect. Lexemes hubb (love), bithiss (you feel), ihtiyāg (neediness) express the positive emotionality, meanwhile the words ta 'arreyt (you undressed), da 'if (weak) and byanhār (here 'dies') indicate to the negative tone.

Another type of sayings is represented with witticisms. Witticisms concerning the man's role in the woman's life play an essential role in the community. For instance, $l \bar{a}$ taḥtāğu al-mar'a li-rağul yaḥullu la-hā ğamī'a mašākili- 
hā walakinna-hā taḥtāğu faqaṭ li-rağul lan yuṣbiḥa muškila fi hayāti-hā (a woman does not need a man to solve all of her problems, but she needs a man who [himself] will not become a problem in her life). In this instance, we observe the simplification of the literary vocabulary - tahtāğu li-rağul (needs a man) is utilized with the preposition $l i$, meanwhile the literary variant requires the usage of the preposition ilā.

The abovementioned simplification may be found in the following instance as well: mundu duhūlì li-tilka alğāmi 'a, wa anā fatāt sayyi 'atu-l-mizāğ wa sa-uṣbih qātila qarīban (since I had entered that university, I became a girl with a bad mood and I will become a killer soon). The literary expression dahala al-ğāmi 'a (enter a university) is utilized in the colloquial variant dahala li-l-ğami ' $a$ with the same meaning. However, in MSA, it has a connotation 'enter a building', not an establishment. Additionally, the word mundu (since) is also a colloquialism reflecting the regional phonetic peculiarities, i.e. a letter $\underline{d}$ from the literary equivalent mund $u$ is substituted with $d$. On the other hand, we observe the relation of 'bad mood' to the lexeme 'killer' obviously having the negative expressivity.

Sometimes the code-switching from the literary form to the colloquial language serves to express the moral of a modern aphorism in a witty way:

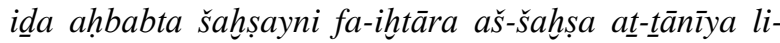
anna-ka law ahbabta al-awwala mā daqqa qalbu-ka li-t-

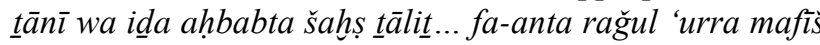
fa'ida fi- $k$

(If you have fallen in love with two people you choose the second person, because if you loved the first person your heart would not have started beating for the second one. But if you have fallen in love with the third one... then you are a prostitute, not a man, and there is no use from you).

The first sentence in the given above text is written in MSA using neutral lexis except the idiom daqqa qalbu-ka $l i-\underline{t}-\underline{t} \bar{a} n \bar{\imath}$ (your heart started beating for the second person) expressing the emotional state of falling in love. However, the second sentence contains the creative solution to describe a too amorous person - rağul 'urra (a prostitute, not a man). Note here, that the humorous effect is based on the usage of a word 'man' with an obscene lexical unit to entertain the female recipients. The given text contains the wordplay focused on the irrelevant combination of a typical offensive lexeme for women with the word denoting any male.

Witticisms can be posted in the form reflecting the variant between MSA and Colloquial Arabic, i.e. the aforementioned mixed variety: wa-l-bint ilı biğidd hiya $\bar{a}$ ilı ta 'rif tafruq imtā tabqā unțā bi-ma'nā al-kalima wa imtā tabqa bi-l-mi'a rāğil (a strong girl is the one who knows how to distinguish [the moments] when to literally stay a woman and when to stay a man for 100\%). Colloquialisms ili (that), imtā (when) and rāğil (man) are given together with colloquial syntax constructions (for instance, ta 'rif tafruq 'knows how to distinguish' instead of a literary form ta'rif an tafruq). In addition, we observe the substitution ' $y \bar{a}$-alif maqșūra' in lexemes imtā (imtī) and $u n \underline{t} \bar{a}$ (untî), the substitution 'alif - alif maqșūra' in the verb tabqa (stay) and other typical replacements.
Witticisms may provide warnings or advises in a humorous manner. For instance, là ta'manī 'azīztī... fa-rriğāl kullu-hum ḩā'inīn, wa aš-šarîf min-hum lam ta'tī-h al-furșa ba'du! (Do not be credulous, dear... because all men are cheaters, and the noble one has not got such a chance yet!). The language in the abovementioned text is generally standard, except for the word hä'inin (cheaters) given in a colloquial form with the ending $\bar{i} n$ instead of $\bar{u} n$. This is another evidence of code-mixing between Standard and Colloquial Arabic in everyday speech.

Witticisms cover ironic puns concerning some particular issues. The realization of some misconception may be expressed with the wordplay: marhala anna-k miš qādir tuțabțib 'alā had, li-anna-k mustahlik kull țāqata-k fì anna-k tubeyyin anna-k qawiy wa miš muhtāğ tabtaba min had! (That period when you are incapable of chatting with anyone because you waste all your energy to explain that you are strong and do not need to chat with anyone!). The pun is based on the alternation of words qädir (capable) and muhtāğ (needing) and the repetition of the word tabtaba (chatting). The combination of words marhala anna- $k$ (literally 'a period that you') reflects the peculiarities of online creativity - the given expression is widely utilized in Internet memes. The saying itself is written in Colloquial Arabic. The literary word tabțaba (babbling) gains the meaning 'chatting' in the youth slang. The informal usage of the abovementioned word results in the variation of the preposition utilized inside one saying tuțabtib 'ala had (you chat with anyone) and tabtaba min had (chatting with anyone).

In the instance below, the humorous effect is created by a hyperbolized reaction expressed with verbs possessing the explicit negative emotionality (ahsudu 'I am jealous', ahqidu 'I despise', akrihu 'I hate'): al-maḩzūzāt hunna man ya'kulna al-aḥ̂ar wa al-yābis wa lā yazīd waznu-hunna... anā aḥsudu-hunna, anā aḥqidu-hunna, anā akrihu-hunna (lucky girls are those who eat everything and do not gain weight... I am jealous of them, I despise them, I hate them). The message is written in MSA. It contains an idiom al-ahdar wa al-yābis (literally 'green and dry') 'everything' which is generally utilized in a negative context (for example, ahraqa al-ahdar wa al-yābis 'burn everything down'). Obviously, we observe the parallel between 'burning everything' and 'eating everything', given that the girls 'eating everything' and staying slim are 'hated'. As we have already mentioned, turning to such offensive means is typical for the online communication (see the instance with an obscene lexeme 'urra).

Conclusion. The lexicon of Arabic Internet sayings for women demonstrates the effect of modern technologies and global tendencies on the language variation in the virtual space. Culture and language contacts on Facebook lead to the lexical interference. We find the usage of calques (șana 'a qarāran 'make a decision') and borrowed connotations (ğunūn 'craziness'). Social media lexis requires the creation of equivalents for the popular slang words (tabtaba 'babbling' is interpreted as 'chatting'). Besides the impact of English, the vocabulary of the given sayings is affected by the diglossic situation in the Arab world. We observe both the code-mixing and the codeswitching involving MSA and different forms of Colloquial Arabic. In the case of code-mixing, a particular 
variant prevails (mainly MSA) in a message and some lexical units (i.e. colloquialisms) are added to make it closer for the female recipients. The code-switching frequently occurs when an author uses first MSA and then shifts to Colloquial Arabic to create a humorous effect.

The provided instances indicate that Internet sayings for women cover the topics of love, men, beauty and success. The vocabulary transmits deep emotional states (from happiness and joy to hate and suffering) expressed with lexemes having both traditional understanding and modern interpretations (for example, craziness). Female sayings contain obscene lexical units and offensive expressions to transfer the attitude toward the popular issues discussed on Facebook (men's behaviour, overweight, bad mood, etc.). Additionally, the creativity in the studied online community includes the language game. It affects the lexicon utilized for the wordplay and results in the occasional usage of irrelevant modifiers (for instance, the word käfir 'tough'), the relexicalization of collocations (for instance, the idiom al-ahdar wa al-yābis 'everything') and other.

The herein study indicates that the examined sayings posted by and mainly for female users cover the lexis of MSA, colloquialisms, slang words, loanwords, obscene lexemes and expressions, idioms, etc. In the context of online creativity, the given lexicon can be relexicalized in order to express some emotional state, attitudes and other. The code-switching and the code-mixing between MSA and Colloquial Arabic are utilized in terms of informal online discourse and need the in-depth analysis of its lexical, morphological, phonetic and other peculiarities. Although this research is relatively small, it has important implications for the further sociolinguistic studies of Arabic language variation on the web.

\section{REFERENCES}

1. Al-Shool, S. Politeness and Gender in the Arabic Discourse of Social Media Network Websites: Facebook as a Norm // International Journal of Linguistics, 2016. 8 (3). P. $31-58$.

2. Androutsopoulos, J. From Variation to Heteroglossia in the Study of Computer-Mediated Discourse // Digital Discourse: Language in the New Media, 2011. P. 277 - 298.

3. Guiller, J. and Durndell, A. Students' linguistic behaviour in online discussion groups: Does gender matter? // Computers in Human Behavior, 2007. 23 (5). P. 2240 - 2255.

4. Hadžiahmetović Jurida, S. Linguistic properties and aspects of blogging within the context of Netspeak // Jezikoslovlje, 2013. 14(2-3). P. 517 - 536.

5. Jarbou, S. O. and Al-Share, B. The Effect of Dialect and Gender on the Representation of Consonants in Jordanian Chat // Language@Internet, 2012. 9. Available at: http://www.languageatinternet.org/articles/2012/Jarbou.

6. Kadir, Z. A., Maros, M. and Hamid, B. A. Linguistic Features in the Online Discussion Forums // International Journal of Social Science and Humanity, 2012. 2 (3). P. 276 - 281.

7. Kucherenko, A. Some Features of Postfolklore in Arabic Online Communication //
Komunikacija i kultura online, 2016. VII (7). P. 1 - 21. Available at: http://doi.fil.bg.ac.rs/volume.php?pt=journals\&issue=kkonlin e-2016-7-7\&i=1

8. Thompson, Sharon H. and Lougheed, E. Frazzled by Facebook? An Exploratory Study of Gender Differences in Social Network Communication among Undergraduate Men and Women // College Student Journal, 2012. 46 (1). P. 88 - 98.

9. Sadat, F., Kazemi, F. and Farzindar, A. Automatic Identification of Arabic Language Varieties and Dialects in Social Media // Proceedings of the Second Workshop on Natural Language Processing for Social Media, 2014. P. 22 - 27.

10. Ramsay, G. What kind of Arabic and why? Language in Egyptian blogs // Orientalia Suecana, 2012. LXI. P. 49 - 87.

11. New Global Social Media Research [online]. Available at: https://www.smartinsights.com/social-mediamarketing/social-media-strategy/new-global-social-mediaresearch/

12. WomenNewsPaper [online]. Available at: https://www.facebook.com/WomenNewsPaper/

\section{Лексические особенности арабских Интернет-высказываний для женщин}

\section{А. А. Кучеренко}

Аннотация. Данная статья касается лексических средств в арабских Интернет-высказываниях для женщин. Исследование относится к современным афоризмам, остроумным высказываниям, мотивирующим выражениям и т.п. Они отражают язык, используемый в ежедневной коммуникации. С одной стороны, разновидности арабского языка включают литературную и разговорную формы, которые могут смешиваться для упрощения взаимопонимания между арабами из разных стран. Особое внимание также уделяется переключению и смешиванию кодов литературного и разговорного арабского языка. С другой стороны, мы рассматриваем влияние Интернета на арабский язык и анализируем творческий аспект, который воздействует на женский онлайн-дискурс.

Ключевые слова: Интернет-высказывание, женский дискурс, разновидность арабского языка, лексическая интерферениия, разговорная лексика, сленг. 